\title{
'Legends' in 'Lingerie': Sexuality and Athleticism in the 2013 Legends Football League US Season
}

ARTICLE in SOCIOLOGY OF SPORT JOURNAL · MARCH 2015

Impact Factor: 0.75 · DOI: 10.1123/ssj.2014-0054

READS

142

2 AUTHORS:

Anastasiya Khomutova

UCFB Wembley

4 PUBLICATIONS 0 CITATIONS

SEE PROFILE
Alex Channon

University of Greenwich

10 PUBLICATIONS 14 CITATIONS

SEE PROFILE 
“"Legends' in 'Lingerie': Sexuality and Athleticism in the 2013 Legends Football League US Season"

by Khomutova A, Channon A

Sociology of Sport Journal

(C) 2015 Human Kinetics, Inc.

Note. This article will be published in a forthcoming issue of the Sociology of Sport Journal. The article appears here in its accepted, peer-reviewed form, as it was provided by the submitting author. It has not been copyedited, proofread, or formatted by the publisher.

Article Title: 'Legends' in 'Lingerie': Sexuality and Athleticism in the 2013 Legends Football League US Season

Authors: Anastasiya Khomutova ${ }^{1}$ and Alex Channon ${ }^{2}$

Affiliations: ${ }^{1}$ Faculty of Physical Culture, Palacky University, Olomouc, Czech Republic. ${ }^{2}$ Faculty of Education and Health, University of Greenwich, London, United Kingdom.

Running Head: 'Legends' in 'Lingerie'

Journal: Sociology of Sport Journal

Acceptance Date: August 6, 2014

(C)2015 Human Kinetics, Inc.

DOI: http://dx.doi.org/10.1123/ssj.2014-0054 
“"Legends' in 'Lingerie': Sexuality and Athleticism in the 2013 Legends Football League US Season"

by Khomutova A, Channon A

Sociology of Sport Journal

(C) 2015 Human Kinetics, Inc.

\begin{abstract}
This paper explores the representation of female athletes within the Legends Football League (LFL; formerly 'Lingerie Football League') in 2013. Specifically, the study seeks to understand the vision of women's sport, and female athletes, which the LFL propagates. Drawing on a combined content and semiotic analysis of the commentary and visuals featured in 26 LFL matches broadcast online in 2013, our data suggests that the LFL presents apparently conflicting images of sexualised, but 'powerful' female athletes. We discuss these data relative to competing interpretive approaches to female sexuality in sports media, and join other sports media scholars in advocating audience reception research as a necessary next step to grasping this emergent sport's significance.
\end{abstract}


“"Legends' in 'Lingerie': Sexuality and Athleticism in the 2013 Legends Football League US Season"

by Khomutova A, Channon A

Sociology of Sport Journal

(C) 2015 Human Kinetics, Inc.

\section{Introduction: The Legends Football League}

In 2004, during the halftime show of the National Football League (NFL) Super Bowl match, a pay-per-view, one-off exhibition gridiron football game was staged, featuring two teams of female competitors playing to modified rules - and all of them wearing 'lingerie'. ${ }^{1}$ Based on the premise that such revealing game kits would attract (male) television viewers (Shepherd, 2010), this so-called 'Lingerie Bowl' appeared to be a commercial success, despite the controversy surrounding its flagrantly sexualised format (Knapp, 2013; Weaving, 2014). On the basis of this success, further Lingerie Bowl matches were held in 2005 and 2006, leading to the eventual creation, in 2009, of the 'Lingerie Football League' (LFL).

Between 2009 and 2012, the LFL expanded to feature 12 teams across the United States, organised in two regional conferences, with seasons featuring weekly matches running over a period of 20 weeks. The LFL also moved from the limited broadcasting reach of payper-view television to a prime-time slot on the MTV2 channel, and subsequently in 2013 to the internationally-accessible video sharing website, YouTube. Its apparent growth in viewership, expanding global recognition, and establishment of team franchises in both Canada and Australia (and current plans to do the same in Europe), prompted writers on the LFL's media outlet to predict that "by late 2014 the LFL will be seen in more international households than the National Football League" (de la Fuente, 2013).

Despite this rise in visibility, the LFL thus far remains relatively under-explored in academic sports scholarship, with only two very recently published papers directly addressing this phenomenon: Knapp's (2013) analysis of newspaper and magazine articles on the LFL, and Weaving's (2014) philosophical commentary on the league. Both of these papers discuss the LFL primarily in light of the highly sexualised constructions of gender which it presents arguably its most salient characteristic - such that the LFL's 'unique selling point' has also made it a target for scholarly criticism. Evaluating the organisation from a critical feminist 
“"Legends' in 'Lingerie': Sexuality and Athleticism in the 2013 Legends Football League US Season"

by Khomutova A, Channon A

Sociology of Sport Journal

(C) 2015 Human Kinetics, Inc.

perspective, Knapp ultimately forwards the conclusion that the LFL "thwarts any (gender) subversion" (2013: 15) that women's engagement in football might otherwise pose to dominant sexual hierarchies, while Weaving (2014: 8) applies the familiar logic of antidoping arguments to suggest that the LFL's "hypersexualisation" is unfair, harmful, and contravenes the 'spirit' of sport. Both writers are thus deeply sceptical about the LFL, and their arguments echo the critical reaction common within many journalistic reports of the organisation (e.g., Linden, 2012; Marshall, 2012; Shad, 2012).

However, in January 2013, the LFL underwent a rebranding exercise, having changed its name to the 'Legends Football League', removing overt sexual imagery from its logo and altering its uniform regulations (LFL360, 2013a). ${ }^{2}$ Claiming to be shedding the image of a sexualised, sideshow gimmick in favour of focusing on its players as authentic athletes and its matches as genuine sporting spectacles, the LFL today appears to be attempting to reposition itself as a legitimate (or 'real') sports phenomenon (LFL360, 2013b; Piachard, 2013; Weaving, 2014). This rebranding exercise arguably came as a response to the mounting criticism which the LFL has faced following its expansion out of relative obscurity and attempt to penetrate new global markets. That the announcement of its rebranding coincided with the acceleration of the LFL's move towards a wider global presence (including team try-outs held in Australia and Europe, and a promotional tour throughout East Asia during early 2013), as well as the announcement of a videogame deal, is strongly suggestive of a shift in marketing strategy as the organisation attempts to broaden its appeal to, supposedly, a wider and more 'mainstream' audience beyond its original targeted demographic of "beer-drinking college students aged 21 and up" (Shepherd, 2010).

The extent to which this rebranding genuinely changed the LFL is questionable (Weaving, 2014), as the actual uniforms worn by players for the 2013 season were not significantly different, least of all regarding how revealing they were of players' bodies 
“"Legends' in 'Lingerie': Sexuality and Athleticism in the 2013 Legends Football League US Season"

by Khomutova A, Channon A

Sociology of Sport Journal

(C) 2015 Human Kinetics, Inc.

(Chandler, 2013). Nevertheless, this exercise does involve a significant shift in the way that its players are discursively framed, moving from an overtly feminine, explicitly sexual construct ('lingerie') to a gender-neutral one inferring both excellence and iconic sporting status ('legends'). As such, the LFL's rebranding begs the question as to exactly how it locates female athletes within the ostensibly competing paradigms of 'soft porn' and 'athletic competence' (Kane \& Maxwell, 2011) - a key battleground in contemporary debates over the significance, and social value, of mediated women's sport. While previous efforts to evaluate the LFL have addressed these themes by way of examining external and peripheral media texts (Knapp, 2013), or through a predominantly theoretical lens (Weaving, 2014), this paper explores the LFL's representation of female athletes by way of empirically investigating its central media product - the broadcast matches of an entire LFL season. The paper begins with a brief discussion of previous literature on the media 'sexualisation' of female athletes as a way to contextualise this data.

\section{Athleticism, Sexualisation, and Female Athletes}

In previous studies of women's sport, and in particular of female athletes in the media, the relationship between sport and sexuality has been a centrally important, contested issue. One of the major debates in this area has revolved around the question of 'sexualisation', as the phenomenon of emphasised female heterosexuality has been seen to impact upon the gender-subversive, empowering potential of female athleticism. In this respect, debate has tended to coalesce around two opposing readings of the sexualisation of athletes, stressing either the incompatibility of athleticism and athlete sexualisation, or their reconcilable character within specific contexts. ${ }^{3}$

The former position, which has tended to appear most widely within studies of female athletes' sexualisation, principally locates emphasised female heterosexuality in sport as a 
“"Legends' in 'Lingerie': Sexuality and Athleticism in the 2013 Legends Football League US Season"

by Khomutova A, Channon A

Sociology of Sport Journal

(C) 2015 Human Kinetics, Inc.

trivialising backlash against the social advancements made by women through their athletic participation (e.g., Bernstein, 2002; Cooky \& LaVoi, 2012; Kane \& Lenskyj, 1998; Lenskyj, 2012; Messner, 2002). This critique begins from a recognition of women's historical struggle for acceptance in sport, as feminist sport scholars have consistently highlighted the importance of women's achievement in this cultural arena as a means of challenging entrenched male social advantages (e.g., Hargreaves, 1994; Pfister, 2010; Roth \& Basow, 2004; Theberge, 1987). However, the general tendency for the mass media to ignore women's sport, or report on it in variously 'trivialising' ways, has largely blunted the otherwise gender-subversive cultural significance of this phenomenon (Duncan \& Hasbrook, 1988; Messner, 2002).

One such form of trivialised reporting sees female athletes given attention in ways which directly emphasise their (hetero)sexuality, whilst downplaying their athletic ability. The manner in which this sexuality is signified typically promotes readings of women's bodies which emphasise weakness, passivity, and sexual violability (Heywood \& Dworkin, 2003). Thus turning attention away from their embodiment of physical power, this reductive re-framing sees athletes' bodies made most visible when they emphasise a form of physicality broadly oppositional to the agentic power denoted by the supposedly 'masculine' attributes of tough, muscular athleticism (Carty, 2005; Jones et al., 1999; Kane et al., 2013; see also Dowling, 2000). The sexualisation of female athletes thereby neuters the subversive potential of women's sport by reaffirming images of heterosexual (and thus, supposedly 'normal') women as weaker than, and therefore vulnerable to, heterosexual/'normal' men.

This critique also suggests that sexualisation encourages the commodification and valuation of female athletes' bodies principally on the basis of sex appeal, and in this sense, the bodies of sexualised athletes become principally 'bodies-for-others', celebrated through media visibility as the objects of heterosexual male desire (Davis, 2010; McLeod, 2010). 
“"Legends' in 'Lingerie': Sexuality and Athleticism in the 2013 Legends Football League US Season"

by Khomutova A, Channon A

Sociology of Sport Journal

(C) 2015 Human Kinetics, Inc.

Given the alienating, psychologically damaging consequences of this objectification, which casts women's bodies as the effective sexual possessions of others, increasingly normalised sexualisation is argued to operate as a repressive force working against women's interests (American Psychological Association, 2007; Carty, 2005; Daniels, 2009). Within the context of sport, promoting conformity to the view that women's bodies be valued only through their appeal to male desire clearly runs against the promise of athletic embodiment as a selfactualising process of empowerment (Heywood \& Dworkin, 2003; Weaving, 2014).

Finally, as sexualised sports media disproportionately celebrate women who are most openly and obviously heterosexually attractive, this phenomenon is also implicated in the homophobic stigmatisation and exclusion of supposedly unattractive, 'masculine' athletes, leading to the relatively low visibility of these, as well as openly lesbian, sportswomen in media spaces (Bruce, 2012; Messner, 2002). In addition, the tendency for most media coverage of this type to be given to 'white' athletes reinforces the cultural validation of 'whiteness' as normative, to the relative exclusion, vilification, or specific, racially-patterned sexualisation of non-'white' women (e.g., Cooky et al., 2010; Schultz, 2005). Thus, this selective, reductive objectification of (mostly) heterosexual, 'white' women conflates gender, sexuality and 'race' in variously harmful, socially exclusive ways, whilst eroticising a gendered disparity in physical and social power which recreates the exact sexual hierarchy which women's participation in sport is otherwise thought to counter.

In contrast to this position, the latter reading of emphasised feminine heterosexuality suggests that sexualisation need not be seen as fundamentally oppositional to women's empowerment (Messner, 2002; Thorpe, 2008). Through highlighting various reclamations and re-articulations of hetero-feminine aesthetics (such as the influential 'Riot Grrrl' music scene of the 1990s, or 'Girlie' fashion/lifestyle - see Baumgartner \& Richards, 2000; Gilley, 2005; Klein, 1997; Schilt \& Zobl, 2008), the notion that sexualised femininity is purely an 
“"Legends' in 'Lingerie': Sexuality and Athleticism in the 2013 Legends Football League US Season"

by Khomutova A, Channon A

Sociology of Sport Journal

(C) 2015 Human Kinetics, Inc.

expression or by-product of male domination has been questioned via attention to women's agency, along with shifting definitions of what counts as heterosexually attractive feminine embodiment. Perhaps the most influential application of this position in sport scholarship is to be found within Heywood and Dworkin's book, Built to Win, wherein the authors claim that an "expanded possibility" (2003: 78) of female embodiment exists when athletes are increasingly seen to embody both 'masculinity' and 'femininity' in numerous, diverse ways. While reductive forms of sexualisation are still seen to operate through hetero-feminine symbols, this is recognised as but one way in which female sexuality is gendered and represented, which can also involve "ambiguous, varied, or empowering images" (Lerum \& Dworkin, 2009: 254). Such images can be generated when 'sexy' female athletes

redeem the erasure of individual women that the old Playboy model of sexualisation performed, rewriting the symbology of the female body from empty signifiers of heterosexual access... to the active, self-present sexuality of a body that signifies achievement and power. (Heywood \& Dworkin, 2003: 82)

This 'redemption' of female heterosexuality is made possible through effectively combining masculinised and feminised qualities, towards the production of a 'sexy' body which is not reduced solely to that sexual quality, nor constructed as powerless or passive in the process (Baumgartner \& Richards, 2000; Carlson, 2010; Klein, 1997). In this respect, the erotic framing of physically powerful women can treat sex and athleticism as equally potent signifiers, mutually coexisting in ways which cast female athletic embodiment as (hetero)sexually desirable in similar ways as to how male athletes' bodies long have been and continue to be - sexually valued by both women and men (Guttmann, 1996; Pronger, 1990).

This position troubles the assumption that consuming sexualised imagery always bears damaging consequences for women (cf. Lerum \& Dworkin, 2009), and disrupts the 
“"Legends' in 'Lingerie': Sexuality and Athleticism in the 2013 Legends Football League US Season"

by Khomutova A, Channon A

Sociology of Sport Journal

(C) 2015 Human Kinetics, Inc.

notion that female passivity sees women forcibly rendered as 'sex objects' by/for the exploitive male gaze. In this regard, it is argued that women, heterosexual or not, might consciously embody (hetero)sexy feminine styles of their own volition, for reasons other than blind, alienating conformity with male desire (e.g., Caudwell, 2006; Heywood, 2008; Heywood \& Dworkin, 2003; Thorpe, 2011). The role of women's agency in simultaneously embodying (hetero)sexy femininities and 'empowered' subjectivities has been discussed in a range of empirical and theoretical papers on women's sport and leisure, including those on athletes/fans' nudity (Heywood \& Dworkin, 2003; Valentich, 2014), recreational/competitive pole dancing (Petersson McIntyre, 2011; Whitehead \& Kurz, 2009), striptease (Ross, 2007), cheerleading (Moritz, 2011), erotic wrestling (Scambler \& Jennings, 1998), snowboarding (Thorpe, 2008; 2011), and roller derby (Breeze, 2010; Carlson, 2010; Finley, 2010; Pavlidis, 2012). Here, the possibility of feeling empowered either through or regardless of heterofeminine embodiment in such activities troubles the notion that emphasised, heterosexual femininity is always the product of alienating cultural forces which victimise, objectify and exploit women whilst undermining their athletic achievement. Taken alongside an understanding of sports as fundamentally erotic, embodied phenomena (Guttmann, 1996), which bear an ever-present potential for sexual significance in ways which "do not inevitably betoken ideological invasion" (Davis, 2010: 62), the performance of overt, hetero-feminine sexuality by female athletes ought not to be interpreted as disempowering by default.

Without rejecting its arguments outright, this alternative to the 'reductive objectification' thesis opens a wider range of readings of overt representations of female heterosexuality, thereby recognised as "more complicated than the simple reduction of a woman to a "piece of ass"' (Heywood \& Dworkin, 2003: 83). Instead, the question becomes one of interrogating their specific manifestations, exploring exactly who, how and what such representations signify. Yet, while the existence of this perspective has often been noted in 
“"Legends' in 'Lingerie': Sexuality and Athleticism in the 2013 Legends Football League US Season"

by Khomutova A, Channon A

Sociology of Sport Journal

(c) 2015 Human Kinetics, Inc.

media studies of female athletes, it has only rarely been utilised analytically in explaining empirical phenomena. This is perhaps the case given that the historical tendency for sports media to focus on female (hetero)sexuality accompanies a general silence regarding women's athletic capabilities; a phenomenon that has been well documented (e.g., Bernstein, 2002; Bruce, 1998; Cooky et al., 2013; Messner and Cooky, 2010; Messner et al., 2003; etc.), rendering this redeemed femininity hypothesis more-or-less moot. However, the possibility remains for interpreting 'sexy' female athletes within multiple different, intersecting and sometimes ostensibly contradictory or ambivalent frames (e.g., Jirasek et al., 2012; King, 2013), and within contexts where women's athleticism and physical power is not otherwise flatly ignored by sports media, such a sensitivity of interpretation becomes all the more meaningful.

Our investigation of the LFL begins at this juncture. At first glance, the LFL appears as one of the most striking contemporary examples of female sexual objectification in sport; it has historically been marketed almost entirely on sex appeal, taking a format which one would certainly not expect to see within equivalent male sports (Fink, 2012; Weaving, 2014). However, the organisation's 2013 rebranding exercise supposedly rests on an attempt at reconciling its 'sex sells' marketing strategy ${ }^{4}$ with a new-found public identity as 'real' sport, despite the historical tendency in Western cultures for athleticism and (hetero)sexy femininity to be constructed as oppositional. More compellingly though, is the LFL's athletic heritage as a variant of what is popularly imagined as one of the most 'masculine' of all modern sports - American gridiron football. As a full-contact, territorial team game, with the basic premise of violently overcoming one's opposition in brutally physical, fast-paced mock battles, gridiron football symbolically aligns not only with Western ideals of culturally valorised, 'warrior' masculinity (Messner, 1988), but more specifically, also with heteronormative (penetrative) male sexuality (Pronger, 1999). 
“"Legends' in 'Lingerie': Sexuality and Athleticism in the 2013 Legends Football League US Season"

by Khomutova A, Channon A

Sociology of Sport Journal

(c) 2015 Human Kinetics, Inc.

Combining this hyperbolically masculinised, power-laden athletic pedigree with overtly sexualised, hetero-feminine aesthetics may well reflect the cultural need to 'make safe' the otherwise transgressive performance of 'female masculinity' within such sports. But this also begs the question as to where the variously gendered symbolism of the LFL leaves its resultant representation of 'culturally safe' femininity, and how exactly such a construct fits within competing interpretive approaches to female athletes' sexualisation. This concern ultimately forms the basis of our research questions for this present study: how exactly does the LFL, as a notoriously sexualising enterprise, represent female athletes within its broadcast matches? More specifically, what competing readings of female sexuality and athleticism emerge from its media product? And of these, which (if any) appear most prominent?

\section{Methodology}

In order to answer these questions, we set out to explore the LFL via an analysis of the discursive and visual content of the matches comprising its 2013 US season, which were accessible between March and September 2013 through its official channel on the video sharing website, YouTube. In doing so, we adopted two methods as a means of gathering both qualitative and quantitative data. Epistemologically, we felt this approach was necessary in order to understand both the complex inscription of meanings within the LFL's representation of players and play, and the regularity/consistency with which such meanings were deployed. While rich, qualitative descriptions of imagery and commentary are vital for capturing a sense of the cultural messages communicated through sports programming, these cannot accurately reveal the wider representational tendencies broadly operating across such media products. Meanwhile, quantified measurements of those tendencies do provide such an insight by charting these products' overall orientation relative to specific practices of 
“"Legends' in 'Lingerie': Sexuality and Athleticism in the 2013 Legends Football League US Season"

by Khomutova A, Channon A

Sociology of Sport Journal

(C) 2015 Human Kinetics, Inc.

signification, although such data often remain too abstract to adequately represent the meanings invested within them. As such, combining quantitative and qualitative data can provide broader insight into the messages articulated through sports media than simply adopting one of these approaches alone.

The methods chosen for these two tasks were (qualitative) semiotic analysis and (quantitative) content analysis. Semiotic analysis is an interpretive method involving "( $\mathrm{t}$ )he study of signs" (Kennedy \& Hills, 2009: 14) within texts (such as images, words, etc.) which is attentive to both their 'denotative' (explicit) and 'connotative' (implicit) content, and with reference to their relationship with other signs, either through contextual association ('syntagmatic' sequences of signs) or usage in place of possible alternatives ('paradigmatic' selection of signs) (Barker, 2012). This method enables researchers to identify how the specific, superficial materials presented through media texts communicate ideologicallyloaded messages within wider structures of meaning, relative to associated and conspicuously absent, alternative content (Stokes, 2013). For instance, the denotative content of video composed of female athletes playing a full-contact team sport whilst wearing bikinis carries possible connotations relative to cultural discourses of femininity, sexuality and sport (among others), which are constructed through the paradigmatic choices in the text's production including, for instance, the format of the game being played - and their syntagmatic connection with other signifiers - such as the roles assumed by men around the game, or the content of game commentary. Thus, a semiotic analysis of the meaning of such video entails attending to various contextual elements of its overall production.

Acknowledging this 'intertextuality' involved within LFL programming (that is, the "accumulation of meaning across different texts or images" (Kennedy \& Hills, 2009: 20)) necessitated studying both the video and audio elements of its broadcasts. While we gathered qualitative data for both, we also conducted a systematic, quantitative measure of the 
“"Legends' in 'Lingerie': Sexuality and Athleticism in the 2013 Legends Football League US Season"

by Khomutova A, Channon A

Sociology of Sport Journal

(C) 2015 Human Kinetics, Inc.

commentary, accounting at least partially for the regularity of signification within LFL matches. While the epistemological basis of content analysis typically appears closer to positivism than the fundamentally interpretive character of semiotics, quantified measures of signification (such as those used here) are in fact rooted in interpretation; such quantification begins with analysts deciding upon how to recognise and categorise signifiers making up the content of texts (Stokes, 2013), such that content analysis is not necessarily at odds with the philosophical underpinnings of qualitative media research. In this respect, a quantitative content analysis is effectively an effort to map syntagmatic patterns (interconnected series of signs) by way of highlighting the specific paradigmatic arrangements within texts (i.e., the regularity of specific connotations versus others). Such measurements ultimately allow scholars to speak with enhanced confidence as to the commonality of important forms of signification within the texts they study, making a valuable contribution to semiotic analyses.

It should be noted, however, that we do not present this mixing of methods as a positivistic triangulation technique aimed at cross-checking data or ensuring a 'complete' understanding of the LFL (cf. Gibson, 2012). Indeed, these methods remain limited to our interpretive abilities as researchers, as well as our exclusive focus on the LFL match content (rather than, for instance, its audience reception or marketing materials), such that producing a comprehensive interpretation of the LFL remains beyond the scope of this study. Rather, our approach is argued to produce different but complementary sets of empirical data useful for addressing our broader research interest (Spicer, 2012), allowing us to explore both the complexity of gender significance deployed within LFL programming and the relative frequency with which differing constructions of gender became salient.

As for conducting the research, we began by developing a thematic coding framework for our content analysis through which to record frequencies of the gender-signifying motifs used by LFL commentators. Taking our lead from the theoretical positions outlined above, as 
“"Legends' in 'Lingerie': Sexuality and Athleticism in the 2013 Legends Football League US Season"

by Khomutova A, Channon A

Sociology of Sport Journal

(c) 2015 Human Kinetics, Inc.

well as earlier studies of gendered language in sports commentary (e.g., Duncan et al., 1990; Sabo \& Curry Jansen, 1992), we devised a coding system which sought various, potentially sexualising or otherwise 'trivialising' framing of the players/sport, alongside constructions of the LFL and its players as 'real' or 'serious' sport/athletes. Having established this framework, we sought to enhance consistency in our measurements (inter-coder reliability) by taking the first two games of the season as pilot studies. We watched these together, talked openly about our coding, and discussed disparities and disagreements in our interpretations of various items. We then separately re-coded these first two matches and compared counts, and were satisfied that our tallies for each item across the two games were within an agreement margin of $90 \%$ (cf. Neuendorf, 2002). We subsequently divided the remaining 24 broadcasted games of the season (each being approximately one hour in length, inclusive of short pre-game and half-time 'analysis' segments) between each coder, jointly coding two further games later in the season to monitor reliability. Furthermore, after initially coding the first two games, we added four additional thematic items as a response to emergent but unanticipated patterns (items 5, 8, 9 and 17, below). In order to make our coding strategy transparent, and account for the ultimately subjective basis of this quantitative method, we discuss our definitions and reasoning behind each category below.

Given the relative difficulty of accurately quantifying video content, along with the implausibility of directly reproducing it within written reports (Atkinson, 2012), data on the visual content of the LFL were gathered throughout the season in the form of a descriptive note-taking system, logging the notable images on show within the games (i.e., the denotative content) as well as our personal reactions to and interpretations of them (i.e., their possible connotations). Following joint analysis of our notes, a number of the most pertinent extracts were chosen for inclusion in this paper, and are discussed below. While less formal than tallying or transcribing game commentary, this method allowed us to at least partially account 
“"Legends' in 'Lingerie': Sexuality and Athleticism in the 2013 Legends Football League US Season"

by Khomutova A, Channon A

Sociology of Sport Journal

(C) 2015 Human Kinetics, Inc.

for the interpretive experience of watching the LFL, attempting, as Atkinson summarises, to "bring audiences 'closer' to that which has been studied" (2012: 142). In our analysis of these two sets of data, we returned to the competing readings of gender, sexualisation, and female athleticism outlined above, which form the basis of this paper's discussion.

\section{Listening to the LFL}

The LFL broadcast commentary team during the 2013 US season comprised the pairing of 'colour commentator' and former NFL quarterback/LFL coach, Bobby Hewko, with play-by-play announcer and experienced sports broadcaster, Van Earl Wright. Additionally, field reporter Lisa Ligon, the LFL productions' only visible female presence besides the players, appeared in the first ten games, only to be later replaced by LFL commissioner Mitchell Mortazza - who would then subsequently replace Wright on commentary during the final eight games, leaving the field reporter post empty. Thus, the clear majority of the quantified data came via dialogue between two men, reflecting broader trends within American sports broadcasting to marginalise female voices in game commentary (Cooky et al., 2013).

Our coding of this data, the results of which are given in tables 1 and 2 below, depended upon a framework which involved the following categories interpreted as celebrating the players' athleticism and/or constructing the LFL as 'real', legitimate sport: 1) Skill - emphatic praise for players' technical abilities, strategic nous, or general efficacy as footballers; 2) Mentality - noting players' possession of desired psychological qualities, e.g. determination, 'intensity', level-headedness, etc.; 3) Toughness - emphasising players' physical power or resilience, along with descriptors of players as, for instance, 'dominant force', 'offensive weapon', etc.; 4) Athleticism - describing players as athletically gifted or emphasising their superior speed, endurance, agility, etc.; 5) Leadership - whenever players 
“"Legends' in 'Lingerie': Sexuality and Athleticism in the 2013 Legends Football League US Season"

by Khomutova A, Channon A

Sociology of Sport Journal

(C) 2015 Human Kinetics, Inc.

were described as 'natural leaders', 'field generals', etc.; 6) Statistics - discussing or showing players' performance statistics, providing a track record of players' achievements whilst denoting that each play holds lasting importance/relevance; 7) Criticism - highlighting mistakes, which we interpreted as a signal that the LFL was a 'serious' sport, such that players were held to high performance standards $;{ }^{5}$ 8) Excitement - noting the entertainment value of the play, and the tension, drama, and spectacle of each contest; and 9) Seasondiscussing teams' week-to-week form, historical rivalries, playoff chances, etc., placing each game within a broader context of dramatic significance. The following transcribed quotes give an indication of how some of these themes were manifest:

Hewko: 'Jacksonville has no weakness on offence, or defence. They're led by one of the elite quarterbacks in the LFL, K.K. Matheny. She's got a great arm, she can run, just a great field general, and it does not hurt to have the power-back Saige Steinmetz right behind her.'

(Jacksonville Breeze vs. Baltimore Charm, May 25 - italicised items coded 'skill', 'leadership', 'toughness')

Hewko: 'Running back Marirose Roach, she is simply bad to the bone! She runs right up the middle, right toward the centre, then quickly cuts outside, breaks the containment and scores! Unbelievable run by Roach to get Philadelphia on the board!'

(Philadelphia Passion vs. Atlanta Steam, August 17 - coded 'mentality', 'athleticism')

Hewko: Van Earl, that was another drop by Chloe Butler. Her third for the night, I can't believe it! She's usually a clutch player. Salerno can't believe it either... LA does not look like a championship team tonight! Bad snaps, Barba over the head of Salerno right now, this is not the championship team that we know!'

(Seattle Mist vs. LA Temptation, May 4 - both coded 'criticism') 
“"Legends' in 'Lingerie': Sexuality and Athleticism in the 2013 Legends Football League US Season"

by Khomutova A, Channon A

Sociology of Sport Journal

(C) 2015 Human Kinetics, Inc.

Conversely, items coded as a measure of disparaging, overtly sexualising, or otherwise trivialising discourse included: 10) Appearance - discussion of how player's bodies looked, specifically devoid of performance connotations, although without explicit reference to attractiveness; 11) Attractiveness - any comments inviting a reading of players as objects of sexual desire; 12) Sexual humour - making jokes pertaining to sexuality/nudity (see Messner at al., 2003); 13) Lifestyles - any reference to players' lives outside of sport, such as (hetero)sexual/family relationships, non-sporting hobbies, etc.; 14) 'Girls' - as noted in previous studies, describing sportswomen as 'girls' implicitly infantilises them, suggestive of a lack of respect (Duncan et al., 1990; Wensing \& Bruce, 2003); 15) Forenames similarly, referring to sportswomen solely by their forenames indicates an over-familiarity and can be interpreted as infantilising/disrespectful; 16) 'Feminine' adjectives - the use of feminising language to describe the players or game, such as 'cute', 'beautiful', 'feisty', etc., which 'gender-marks' and discursively aligns play with 'female-appropriate' visions of sport (Bruce, 2012); 17) Credit coach - any credit given to the (all-male) coaches, implying a male mastermind was ultimately responsible for the female players' exploits/failures; and 18) Compare NFL - direct comparisons made with the (male) National Football League, or other male sports/athletes, suggesting male standards as those against which women's sport ought to be evaluated. These quotes help to illustrate how such themes were deployed:

Right: 'Jacksonville Breeze and their bench, feeling pretty good about their forty-two point lead.'

Hewko: 'The bench was actually looking pretty good too, Van Earl.'

(Jacksonville Breeze vs. Atlanta Steam, March 30 - coded 'attractiveness')

Hewko: 'Brittany Morgan doesn't have great passing stats tonight, but stats are like bikinis, Van Earl - they show a lot, but not everything!'

Right: 'Haha, now that's a quality line, thank you very much Bobby Hewko.' 
“"Legends' in 'Lingerie': Sexuality and Athleticism in the 2013 Legends Football League US Season"

by Khomutova A, Channon A

Sociology of Sport Journal

(C) 2015 Human Kinetics, Inc.

(Atlanta Steam vs. Omaha Heart, April 13 - coded 'sexual humour')

Right: 'Wow, what a great decision by Seattle head coach Chris Michaelson,

Bobby.' Hewko: 'That's why he is LFL coach of the year, he took Green

Bay points off the board.'

(Seattle Mist vs. Green Bay Chill, April 6 - coded 'credit coach')

Following our content analysis using this coding framework, quantitative data revealed that commentary heavily favoured an overt construction of LFL as 'real' sport, and broadly represented LFL players as tough, skilful athletes (items 1-5). Tables 1 and 2 below illustrate the distribution of these themes by way of total coded items across all games, and per-game averages:

That direct reference to the players' physical appearances or attractiveness, along with sex-themed jokes (items 10-12), were made a combined total of 14 times during 26 games, as opposed to direct praise of the players' various sporting abilities (1-5) being made 2,033 times, is particularly revealing of the paradigmatic choice made in the characterisation of players by LFL commentary. Further, while several other potentially disparaging items (1316) were slightly more frequent, these remained rare by way of comparison to items denoting the seriousness or dramatic excitement/significance of play $(6,8-9)$. The exception here was in crediting the all-male coaching staff, and comparing play with that seen in the NFL (1718), which both occurred relatively frequently. In spite of the generally complimentary descriptions of the athletes themselves (and their largely favourable comparisons with NFL counterparts), these items effectively contributed towards reifying the leadership status of men within this sport (Knapp, 2013), itself further emphasised by way of the mostly-male broadcasting team. This has little direct bearing, however, on constructions of the players' sexualities, which remained relatively conspicuous in their absence from the commentators' framing of play (cf. Bissell \& Duke, 2007). 
“"Legends' in 'Lingerie': Sexuality and Athleticism in the 2013 Legends Football League US Season"

by Khomutova A, Channon A

Sociology of Sport Journal

(C) 2015 Human Kinetics, Inc.

\section{Watching the LFL}

In contrast to the commentary however, the visual content clearly and overtly foregrounded sexual imagery in a number of ways, such that our findings here principally indicated an overt sexualisation of the players. In particular, this involved a continuous and pervasive emphasis on the exposure of players' bodies, arrayed in a manner offering an intimate level of access for the gaze of the audience (cf. Davis, 2010). Of immediate note in this regard were their outfits. Despite the removal of the 'lingerie' accoutrements following its 2013 rebrand (LFL360, 2013a), the LFL uniforms remained cut in such a way as to place a visual emphasis on players' breasts and buttocks. Plunging, V-cut bikini tops, and tightfitting, short trunks with a rear seam running down the centre, accentuated the curvature of these body parts in a clearly deliberate fashion. The visibly arresting sight of two teams taking to the sports field in such attire led us to note the following during the first game of the season:

Players stationed about the field look very strange in safety gear and clothing which covers their shoulders and chest but leaves their cleavage exposed. Audiences are clearly supposed to look at their breasts... the kit very obviously screams, 'sex!'

(Male author, Jacksonville Breeze vs. Atlanta Steam, March 30)

The visual emphasis placed on bust and buttocks was further compounded by the crouching positions which players adopted before the start of each passage of play. While such posture is of importance in the execution of gridiron scrimmaging techniques, this nevertheless provided constant fodder for the cameras, which often adopted low-angle shots from behind each team's offensive/defensive line, focusing on players' provocatively dressed and posed bodies. Furthermore, we noticed that in one game in particular (Seattle Mist vs. LA Temptation, May 4), the visual framing of the plays themselves took place through 
“"Legends' in 'Lingerie': Sexuality and Athleticism in the 2013 Legends Football League US Season"

by Khomutova A, Channon A

Sociology of Sport Journal

(C) 2015 Human Kinetics, Inc.

extensive close-up footage. Although less prominent in other matches, such close-up shots made following the flow of play difficult, as focusing on the players' bodies left viewers incapable of grasping the strategic disposition of the teams on the field.

In time however, we began to notice that the constant visibility of players' exposed bodies became familiar enough to no longer remain at the forefront of our attention. By the midpoint of the season, we were in fact surprised not by the exposure of bodies, but by their occasional covering up:

After watching so many games, I expect the near-nude images as a normal part of the LFL and barely notice that I'm looking at so much skin. I only realised this because I was surprised to see a couple of the players' chests entirely covered by support strapping.

(Female author, Seattle Mist vs. Minnesota Valkyrie, July 6)

Besides their dress, the appearances of the players' bodies themselves were also worthy of note. The LFL reportedly recruits its players at least partially on the basis of their perceived attractiveness (Shteir, 2013), and while there did remain a degree of variation in body shapes among them, players' appearances generally conformed to recognisable, Western standards of (hetero)sexy, 'feminine' beauty. While many had noticeable muscle definition, so too were they largely slim, buxom, had long hair, and regularly wore makeup in addition to eye-blackening face paint. Of further note in this regard is that most teams were composed of players of various ethnicities, whose positioning often reflected the traditional 'racial stacking' of players in (male) gridiron - for instance, the starting quarterbacks were all 'white', while the most high-profile 'black' players tended to be running backs and wide receivers (Coakley, 1990; cf. Berri \& Simmons, 2009). Moreover, during in-game advertisements for the LFL's kit sponsors, where players were mostly shown in what we 
“"Legends' in 'Lingerie': Sexuality and Athleticism in the 2013 Legends Football League US Season"

by Khomutova A, Channon A

Sociology of Sport Journal

(C) 2015 Human Kinetics, Inc.

interpreted as 'passive' poses (standing still, walking slowly, stretching; $n=150$ ), and less frequently performing athletic skills $(n=41)$, we noted that:

The players in the promo segments are not always recognisable as the ones we see doing well in the games, but they are the best looking, and it's mostly the white women in these shots. This is the most obvious example of direct, exclusive focus on players' looks, and it mostly places white women at the forefront.

(Female author, LA Temptation vs. Las Vegas Sin, June 29)

However, while the gratuitous yet selective sexualisation of players' bodies remained a key finding here, and was manifest in multiple ways throughout the LFL's programming, perhaps the other most striking element of its visuals was the emphasis placed on high-impact tackles and blocks. With the physicality of its play easily resembling the "smash mouth football' described elsewhere by Knapp (2012), the LFL consistently featured spectacular hits, which regularly appeared in its highlight clips and promotional videos, as well as being a common element of play. One particularly dynamic, aerial collision was referred to in a highlight clip as 'the greatest hit in the history of football' (Legends Football League, 2013), while another, from earlier in the season, is recounted here in our notes:

Ashley Salerno's hit on Allie Alberts is replayed several times, the crunching impact noise captured on player microphones. Her shoulder-charge connects cleanly, knocks Alberts flat. The crowd gasps, and as Alberts lies concussed, Salerno struts, roars, and hurls the ball in triumph. The player mic picks up her taunt: 'sit the fuck down, bitch!' Commentary eagerly describes the action, rounding off with Hewko's memorable line: 'so far in this game Van Earl, there's no winners, only survivors!'

(Male author, LA Temptation vs. Chicago Bliss, April 19)

Such 'big hits' became the focus of five of the sixteen stand-alone highlight videos posted on the LFL's YouTube channel during 2013, which otherwise showed players delivering pre-game speeches or swearing at each other ( $\mathrm{n}=4$ clips), coaches yelling at players or officials $(n=4)$, and players dancing or celebrating touchdowns $(n=3)$. These short clips, 
“"Legends' in 'Lingerie': Sexuality and Athleticism in the 2013 Legends Football League US Season"

by Khomutova A, Channon A

Sociology of Sport Journal

(c) 2015 Human Kinetics, Inc.

along with their descriptive captions, generally drew attention to how entertaining the LFL was, highlighted the 'intensity' of its competition, or portrayed the players and coaches as tough, 'bad-ass' characters engaged in epic dominance struggles. Such framing was even evident at times when players were shown giving what seemed like overtly sexual performances, such as when one tackler performed the 'twerk' dance (squatting whilst jerking the backside up and down) over her floored opponent's head. As we noted:

Ogom Chijindu spontaneously twerking over Riki Creger-Zier does not come across as a deliberately sexual play for the cameras, but rather aimed at humiliating the tackled player, signifying dominance; a female equivalent of 'screwing' her opponent?

(Female author, Seattle Mist vs. LA Temptation, May 4)

That the LFL chose to valorise this moment in its single, stand-alone highlight video from what had otherwise been a close-fought game between two of its best performing teams is indicative of the premium the organisation places on sexual imagery as its unique selling point. But, while Ogom Chijindu's dancing is certainly reflective of an overtly sexual (and in this case, 'black') hetero-feminine style (cf. Dionne, 2013), its deployment in this manner nevertheless portrayed her as powerful and triumphant, troubling the construction of the dance as inherently sexually objectifying and trivialising of her athletic ability - ability which in fact provided cause for her to perform the dance to begin with. This same connotation was evident within similar physical/verbal taunts exhibited by other tacklers/touchdown scorers (without any noticeable 'racial' patterning), as players used (hetero)sexy dance moves or gendered insults ('bitch', 'skank', 'ho', etc.) as ways of intimidating or celebrating their achievement of dominance over hapless, defeated rivals. That this clearly gendered, overtly sexual posturing might be appropriated for the voyeuristic enjoyment of (male) audiences remains an important consideration, but this does not preclude reading such performances as simultaneously emblematic of the players' embodiment of power. This is particularly so 
“"Legends' in 'Lingerie': Sexuality and Athleticism in the 2013 Legends Football League US Season"

by Khomutova A, Channon A

Sociology of Sport Journal

(c) 2015 Human Kinetics, Inc.

given that these signifying practices most often existed within syntagmatic sequences involving hard collisions, and commentary emphasising 'outstanding' or 'dominating' football plays.

\section{Discussion}

Our analysis of the 2013 LFL US season produced findings which can be interpreted as evidence of the continuation of heteronormative gender construction and the centring of male privilege in sport, yet also of the partial disruption of how such privileges are typically constructed. To begin with, the sexualised visual content of the programming was at many times overt and explicit, through which normative, hetero-feminine (and 'white'-centred) beauty ideals were blatantly being endorsed. The ubiquity of these sexualised visuals can be seen as part of the historical trend for women's visibility within sports media to depend upon both the clear and overt foregrounding of their sexuality, and the amenability of that sexuality to heterosexual male desire. Such a reading is certainly the case in superficial encounters with the sport, but perhaps more worryingly so once the initial 'shock value' of the tiny uniforms and buxom players fades, leading to the normalisation of the audience's expectation to see 'sexy' female athletes near-naked.

Combining this with its narrow range of 'beautiful' body types, within which the majority positioning of 'white' players at the forefront in advertising and promotional segments is also the norm, the LFL's imagery endorses dominant social hierarchies of female bodies in ways which continue to privilege a select group of mostly 'white', hetero-feminine women, while subordinating or excluding others from view. ${ }^{6}$ Furthermore, the men appearing in LFL programming did not have their bodies similarly exposed - nor, evidently, did the LFL appear to privilege normatively 'attractive' male bodies in any sense - such that its asymmetrical positioning of men and women reflected broader cultural expectations that 
“"Legends' in 'Lingerie': Sexuality and Athleticism in the 2013 Legends Football League US Season"

by Khomutova A, Channon A

Sociology of Sport Journal

(C) 2015 Human Kinetics, Inc.

women's bodies ought to be valued on the basis of their sexual attractiveness/availability, whilst men's need not be. And, given that the men appearing in the LFL were shown as authority figures/experts (coaches/broadcasters), or as consumers (fans), the LFL's vision of women's sport was positioned as being produced both by men and for men; in other words, male privilege occupied the clear 'centre' of its programming (Messner, 2002).

However, the LFL's effective re-framing of 'sexy' feminine embodiment also remains worthy of comment. While the visual focus on players' barely-clothed bodies certainly foregrounded their heterosexual attractiveness, these hard, muscular, bruised bodies were nevertheless consistently shown in dynamic, athletic motion, meeting in violent, high-tempo collisions, or strutting and posturing in ways which clearly signified a powerful and assertive sense of self-possession. In so doing, the hierarchally gendered reality which 'sexualised' femininity is typically thought to represent - namely that of women's sexual passivity/vulnerability - was dramatically suspended. And, as contextual backdrop to the evident, gendered contradictions playing out on screen, the commentary consistently framed these images through heavily emphasising the players' skill, toughness, and athleticism in various ways. Given this pervasive construction of the players and play, we suggest that the sexualised visuals of the LFL can (and indeed, are intended to) be read by audiences in ways which are not reductively objectifying, as such.

Thus, the LFL presents ostensibly sexualised female bodies as being invested with power, capable of tough, aggressive, spectacularly 'masculine' athletic performances. These are bodies presented to be lusted after, whilst also simultaneously admired for their athletic capacities. As the players' gendered positioning moved between the hyper-feminine visuals of exposed cleavage and buttocks, and the hyper-masculine, combative athleticism and posturing that forms the mainstay of the sport they play, they signified multiple different meanings relative to these extremes - sometimes more of one than the other, but almost 
“"Legends' in 'Lingerie': Sexuality and Athleticism in the 2013 Legends Football League US Season"

by Khomutova A, Channon A

Sociology of Sport Journal

(C) 2015 Human Kinetics, Inc.

always something of both at once. As such, they problematize binary conceptions of gender, as well as the mutually exclusive positioning of athleticism as essentially powerful, and emphasised, feminine heterosexuality as essentially powerless. In this respect, the sexualised LFL athletes, overtly framed as both 'sexy' and athletic, signify the deconstruction of gendered boundaries dividing sex and athleticism, even if the way they do so involves leaving other, inequitable elements of normative femininity and gender relations relatively intact.

Ultimately then, we argue that the LFL offers an interesting case study into the contestable meanings of (hetero)sexy femininity in sport, within a relatively unique mediasport context which sexualises female athletes not instead of, but alongside showcasing their athletic abilities. With two somewhat oppositional readings in mind, we posit that the construction of femininity evident within the symbology of the LFL remains difficult to analyse from a reductive, dialectical, and dichotomous perspective on sex and athleticism as indices of gender and power. Indeed, it is our contention that the LFL neatly represents the ambiguity captured in Heywood and Dworkin's (2003: 99) assertion that "in the culture of images, we are always dealing with a mixed bag, both/and, not either/or". In meeting the challenge of understanding such phenomena, we concur with these authors' argument against

(persisting), like so much of disciplinary academia, in utilizing critical frameworks that incorporate an either/or kind of frame - images are either oppressive or empowering, setting things back, or moving them forward... We'd much rather live in a culture that idealizes (female athletes as) gorgeously ambiguous (heroes) than a culture that tells us that our being is either reducible to sex or to power, and that for women the two can't mix. (2003: 99) 
“"Legends' in 'Lingerie': Sexuality and Athleticism in the 2013 Legends Football League US Season"

by Khomutova A, Channon A

Sociology of Sport Journal

(C) 2015 Human Kinetics, Inc.

\section{Concluding Thoughts}

Analyses of match broadcasts remain relatively rare within the broad literature on the sexualisation of women in sports media (exceptions include Billings et al., 2002; Bissell \& Duke, 2007; Broch, 2014; Duncan \& Hasbrook, 1998; and Messner et al., 1993), which has most often tended to explore advertising, news and magazine reporting/photography, and other forms of communication peripheral to sporting events themselves. Thus, this present paper contributes towards an under-researched but important area of this otherwise widely debated phenomenon, exploring the topic of sexualisation via the core media production of an overtly sexualised sports league, the LFL. Also, through exploring both the commentary and visual content of matches, our findings reveal disparities and complexities which an exclusive focus on either element of programming might have missed (cf. Bissell \& Duke, 2007). Thus, by adopting a mixed-methods approach through a combined content and semiotic analysis, we have attempted to draw attention to the polysemic potential which the LFL carries, highlighting how sexualised representations within women's sport, dependent upon syntagmatic and paradigmatic context, can be read as existing both within and outside of dominant, hierarchal constructions of gender (cf. Baumgartner \& Richards, 2000; Breeze, 2010; Carlson, 2010; Gilley, 2005; Thorpe, 2008).

However, the extent to which the LFL's athletes might reconfigure the normative meanings of (hetero)sexy femininity, and the power relations so often articulated around these, requires further substantiation than this study alone is able to supply. What remains to be seen in this respect is how viewers adopt various different interpretive frames to make sense of the LFL, and what, if any, effect they have on these viewers' perceptions of female athleticism and sexuality more broadly. And, while our present analysis has treated the LFL as a self-contained phenomenon, this artificial separation from the broader sports/media context(s) within which it is likely to be viewed by spectators around the world also begs the 
“"Legends' in 'Lingerie': Sexuality and Athleticism in the 2013 Legends Football League US Season"

by Khomutova A, Channon A

Sociology of Sport Journal

(C) 2015 Human Kinetics, Inc.

question as to the wider representation of female athletes (and particularly, players of comparable full-contact team games) across the national/cultural settings within which the LFL is played and viewed globally. Culturally sensitive studies of its reception among various audience groups - men/women, casual spectators/long-term fans, viewers/nonviewers of other women's sports, etc. - will thus help to better locate the relative importance of the readings of the LFL which we have attempted to identify, in line with the current move towards audience reception studies within gender and sports media scholarship (e.g., Kane \& Maxwell, 2011; Kane et al., 2013).

It is our hope that this present analysis helps to draw further critical attention among the academic community to this emergent sporting franchise. Additional research concerns, beyond the matter of symbolic representation and audience reception, may arise from this recognition. For instance, the evident power structure within the LFL outwardly appears to exclude the players (and indeed, women more broadly) from policy-making positions, which has clear implications regarding players' exercise of agency and experience of 'empowerment' through the specific negotiation and enactment of their own (hetero)sexy femininities. Secondly, scholars may turn a critical eye more directly on the construction of 'race' and the privileging of 'whiteness' within the league; we have only addressed this very briefly, and more robust analyses of this phenomenon might better account for how 'race' manifests within the LFL in terms of specific forms of sexualisation (Cooky et al., 2010; Schultz, 2005) as well as players'/coaches' lived experience. Thirdly, the issue of safety, insurance provision and remuneration (Shteir, 2013), relative to concerns over the commodification and commercial exploitation of players' labour, should be of pressing concern to researchers interested in player welfare, especially given the risk-laden nature of the physicality of full-contact gridiron football. Thus, while sexualisation, sexuality, athleticism and the league's symbolic construction of sporting femininity are perhaps among 
the more salient concerns at present, other such investigations also remain necessary, particularly if the LFL's global operation continues to expand in coming years.

\section{Notes}

1 The 'lingerie' kit worn by players before 2013 included chokers, bras, panties and garters, each decorated with lace and bows, alongside protective equipment including visored helmets, shoulder pads, elbow pads and knee pads.

2 Following the 2013 rebranding, players' uniforms consisted of relatively unadorned two-piece bikinis, along with similar safety equipment as before.

3 Some readers may recognise the following discussion as symptomatic of broader differences between the socalled second and third 'waves' of feminism (cf. Heywood, 2008; Messner, 2002; Thorpe, 2008). We avoid using these labels here owing to the lack of space required to adequately address the various positions on relevant topics such as sexual agency, empowerment, and other related issues constituting debate occurring within either of these 'waves', as much as between them. To invoke this nomenclature without such explanation risks misrepresenting the complexity of these internally diverse schools of thought, while obscuring the complexity of their historical development (cf. Caudwell, 2011; Gilley, 2005). Given that this paper is not intended to provide a comprehensive commentary on the contested history of recent feminist theory, we instead focus on the specific interpretations made within sport scholarship as to the meanings of female athlete sexualisation, which can be more effectively delineated within the confines of this article.

4 See Kane (2011) and Kane and Maxwell (2011) regarding the questionable efficacy of using sex to sell women's sport.

5 We appreciate that 'criticism' being positioned this way may seem counter-intuitive, and that alternative interpretations of this item (and others) are certainly possible. Previously, scholars of gender and sports media have handled commentator criticism in various ways, such as Kian et al.'s (2009) construction of this as the 'negative' side of a couplet including 'positive' skill and success, or Billings and Eastman's (2002; 2003) focus on differential attribution for success/failure as objects of analysis. Our particular approach was chosen owing to the differing constructions of the LFL, outlined previously, as either a sexualised 'sideshow' wherein sporting action is peripheral and inconsequential, or as 'serious' sport within which success/failure is meaningful and important. Criticising players/teams for their errors is, in our opinion, more likely to help substantiate the latter reading rather than the former. Indeed, criticism of mistakes is certainly to be expected in other (male/female) team sport commentary, hence its inclusion here.

6 Unsurprisingly, a recent list of the 'LFL top 50 hottest athletes of all time', collaboratively produced by the LFL and celebrity gossip website, TMZ, vastly favoured 'white' players (LFL360, 2014). 
“"Legends' in 'Lingerie': Sexuality and Athleticism in the 2013 Legends Football League US Season"

by Khomutova A, Channon A

Sociology of Sport Journal

(C) 2015 Human Kinetics, Inc.

\section{References}

American Psychological Association (2007) Report of the APA task force on the sexualization of girls. Washington: American Psychological Association. Available at: http://www.apa.org/pi/women/programs/girls/report-full.pdf

Atkinson, M. (2012) Key concepts in sport \& exercise research methods. London: Sage.

Barker, C. (2012) Cultural studies: Theory and practice, $4^{\text {th }} \mathrm{ed}$. London: Sage.

Baumgartner, J. \& Richards, A. (2000) Manifesta: Young women, feminism, and the future. New York, NY: Farrar, Straus and Giroux

Berri, D.J. \& Simmons, R. (2009) Race and the evaluation of signal callers in the National Football League. Journal of Sports Economics, 10(1), 23-43. doi: $10.1177 / 1527002508327383$

Bernstein, A. (2002) Is it time for a victory lap? Changes in the media coverage of women in sport. International Review for the Sociology of Sport, 37(3), 415-428. doi: $10.1177 / 101269020203700301$

Billings, A.C. \& Eastman, S.T. (2002) Selective representation of gender, ethnicity, and nationality in American television coverage of the 2000 Summer Olympics. International Review for the Sociology of Sport, 37(3-4), 351-370. doi: $10.1177 / 101269020203700302$

Billings, A.C. \& Eastman, S.T. (2003) Framing identities: Gender, ethnic, and national parity in network announcing of the 2002 Winter Olympics. Journal of Communication, 53(4), 569-586. doi: 10.1111/j.1460-2466.2003.tb02911.x

Billings, A.C., Halone, K.K. \& Denham, B.E. (2002) "Man, that was a pretty shot": An analysis of gendered broadcast commentary surrounding the 2000 men's and women's NCAA Final Four basketball championships. Mass Communication and Society, 5(3), 295-315. doi: 10.1207/S15327825MCS0503_4

Bissell, K.L. \& Duke, A.M. (2007) Bump, set, spike: An analysis of commentary and camera angles of women's beach volleyball during the 2004 Summer Olympics. Journal of Promotion Management, 13(1-2), 35-53. doi: 10.1300/J057v13n01_04

Breeze, M. (2010) There's no balls in derby: Roller derby as a unique gendered sports context. The International Journal of Sport and Society, 1(3), 121-133.

Broch, T.B. (2014) "Smiles and laughs - all teeth intact": A cultural perspective on mediated women's handball in Norway. International Journal of Sport Communication, 7(1), 56-73. doi: 10.1123/IJSC.2013-0133

Carlson, J. (2010) The female significant in all-women's amateur roller derby. Sociology of Sport Journal, 27(4), 428-440

Carty, V. (2005) Textual portrayal of female athletes: Liberation or nuanced forms of patriarchy? Frontiers, 26(2), 132-155. doi: 10.1353/fro.2005.0020 
“'Legends' in 'Lingerie': Sexuality and Athleticism in the 2013 Legends Football League US Season"

by Khomutova A, Channon A

Sociology of Sport Journal

(C) 2015 Human Kinetics, Inc.

Caudwell, J. (2006) Femme-fatale: Re-thinking the femme-inine. In J. Caudwell (Ed.) Sport, sexualities and queer/theory. Oxon: Routledge, pp.145-158.

Caudwell, J. (2011) Sport feminism(s): Narratives of linearity? Journal of Sport and Social Issues, 35(2), 111-125. doi: 10.1177/0193723511406132

Chandler, R. (2013) Lingerie Football League changes uniforms, name in re-branding effort. NBC Sports: Off the Bench. Available at: http://offthebench.nbcsports.com/2013/01/10/theyve-taken-the-lingerie-out-of-thelingerie-football-league/

Coakley, J. (1990) Sports in society: Issues and controversies, $4^{\text {th }}$ ed. St Louis, MO: Mosby.

Cooky, C. \& LaVoi, N. (2012) Playing but losing: Women's sports after title IX. Contexts, 11(1), 42-46. doi: 10.1177/1536504212436495

Cooky, C., Messner, M.A. \& Hextrum, R. (2013) Women play sport, but not on TV: A longitudinal study of televised news media. Communication \& Sport, iFirst article, doi: $10.1177 / 2167479513476947$

Cooky, C., Wachs, F.L., Messner, M. \& Dworkin, S.L. (2010) It's not about the game: Don Imus, race, class, gender and sexuality in contemporary media. Sociology of Sport Journal, 27(2), 139-159.

Daniels, E.A. (2009) Sex objects, athletes, and sexy athletes: How media representations of women athletes can impact adolescent girls and college women. Journal of Adolescent Research, 24(4), 399-422. doi: 10.1177/0743558409336748

Davis, P. (2010) Sexualization and sexuality in sport. In P. Davis \& C. Weaving (Eds.) Philosophical perspectives on gender in sport and physical activity. London: Routledge, pp.57-63.

de la Fuente, M. (2013) LFL: A global sport. LFL360. Available at: http://www.lfl360.com/articles/lfl-global-sport-lfl360-com-marcus-de-la-fuente/

Dionne, E. (2013) The twerking feminist. PolicyMic. Available at: http://www.policymic.com/articles/69657/the-twerking-feminist

Dowling, C. (2000) The frailty myth: Redefining the physical potential of women and girls. New York, NY: Random House.

Duncan, M.C. \& Hasbrook, C.A. (1988) Denial of power in televised women's sports. Sociology of Sport Journal, 5(1), 1-21.

Duncan, M.C., Messner, M.A., Williams, L. \& Jensen, K. (1990) Gender stereotyping in televised sports. Los Angeles, CA: Amateur Athletic Foundation of Los Angeles

Fink, J.S. (2012) Homophobia and the marketing of female athletes and women's sport. In G.B. Cunningham (Ed.) Sexual orientation and gender identity in sport: Essays from activists, coaches, and scholars. TX: Centre for Sport Management Research and Education, pp.49-60. 
“'Legends' in 'Lingerie': Sexuality and Athleticism in the 2013 Legends Football League US Season"

by Khomutova A, Channon A

Sociology of Sport Journal

(c) 2015 Human Kinetics, Inc.

Finley, N.J. (2010) Skating femininity: Gender manoeuvring in women's roller derby. Journal of Contemporary Ethnography, 39(4), 359-387. doi: $10.1177 / 0891241610364230$

Gibson, K. (2012) Two (or more) feet are better than one: Mixed methods research in sport and physical culture. In K. Young \& M. Atkinson (Eds.) Qualitative research on sport and physical culture. Bingley: Emerald, pp.213-232.

Gilley, J. (2005) Writings of the third wave: Young feminists in conversation. Reference \& User Services Quarterly, 44(3), 187-198.

Guttmann, A. (1996) The erotic in sports. Chichester: Columbia University Press.

Hargreaves, J. (1994). Sporting females: Critical issues in the history and sociology of women's sports. London: Routledge.

Heywood, L. (2008) Third-wave feminism, the global economy, and women's surfing: Sport as stealth feminism in girls' surf culture. In A. Harris (Ed.) Next wave cultures: Feminism, subcultures, activism. Oxon: Routledge, pp.63-82

Heywood, L. \& Dworkin, S. (2003) Built to win: The female athlete as cultural icon. London: University of Minnesota Press.

Jones, R., Murrell, A.J. \& Jackson, J. (1999) Pretty versus powerful in the sports pages: Print media coverage of US women's Olympic gold medal winning teams. Journal of Sport and Social Issues, 23(2), 183-192. doi: 10.1177/0193723599232005

Kane, M.J. (2011) Sex sells sex, not women's sports. The Nation, 293(7), 28-29. Available at: http://www.thenation.com/article/162390/sex-sells-sex-not-womens-sports

Kane, M.J. \& Lenskyj, H.J. (1998). Media treatment of female athletes: Issues of gender and sexualities. In L. A. Wenner (Ed.) MediaSport. Boston, MA: Routledge Kegan Paul, pp.186-201.

Kane, M.J. \& Maxwell, H.D. (2011) Expanding the boundaries of sport media research: Using critical theory to explore consumer responses to representations of women's sports. Journal of Sport Management, 25(3), 202-216.

Kennedy, E. \& Hills, L. (2009) Sport, media and society. Oxford: Berg.

Kian, E.M., Mondello, M. \& Vincent, J. (2009) ESPN - the women's sports network? A content analysis of internet coverage of March Madness. Journal of Broadcasting and Electronic Media, 53(3), 477-495. doi: 10.1080/08838150903102519

King, A. (2013) The naked female athlete: The case of Rebecca Romero. International Review for the Sociology of Sport, 48(5), 515-534. doi: 10.1177/1012690212449608

Klein, M. (1997) Duality and redefinition: Young feminism and the alternative music community. In L. Heywood \& J. Drake (Eds.) Third wave agenda: Being feminist, doing feminism. Minneapolis, MN: University of Minnesota Press, pp.207-225. 
“'Legends' in 'Lingerie': Sexuality and Athleticism in the 2013 Legends Football League US Season"

by Khomutova A, Channon A

Sociology of Sport Journal

(C) 2015 Human Kinetics, Inc.

Knapp, B.A. (2012) Smash mouth football: Identity development and maintenance on a women's tackle football team. Journal of Sport and Social Issues, iFirst article, doi: $10.1177 / 0193723512468759$

Knapp, B.A. (2013) Garters on the gridiron: A critical reading of the lingerie football league. International Review for the Sociology of Sport, iFirst article, doi: $10.1177 / 1012690212475244$

Legends Football League (2013) Game 15 WOW Clip: Greatest hit in the history of football. YouTube. Available at: http://www.youtube.com/watch?v=pYhS3p54HFo\&list=PLfS4i_GXOfPyZkLy5q0m UuBKMFhhCpOJa

Lenskyj, H.J. (2012) Gender politics and the Olympic industry. Hampshire: Palgrave Macmillan.

Lerum, K. \& Dworkin, S.L. (2009) "Bad girls rule": An interdisciplinary feminist commentary on the report of the APA Task Force on the Sexualization of Girls. Journal of Sex Research, 46(4), 250-263. doi: 10.1080/00224490903079542

LFL360 (2013a) Lingerie Football League re-brands as Legends Football League. LFL360. Available at: http://www.lfl360.com/articles/lingerie-football-league-re-brandslegends-football-league-lf1360-com/

LFL360 (2013b) Legends Football League strengthens its partnership with Total Sports Asia. LFL360. Available at: http://www.lf1360.com/articles/legends-football-leaguestrengthens-partnership-total-sports-asia-lfl360-com/

LFL360 (2014) LFL Global and TMZ Sports team to present, top 50 hottest LFL athletes of all-time. LFL360. Available at: http://www.lfl360.com/usa/lfl-global-tmz-sportsteam-present-top-50-hottest-lfl-athletes-all-time/

Linden, A.D. (2012) Goalposts: Tackling the last bastion of male monopoly. On The Issues Magazine: A Magazine of Feminist, Progressive Thinking. Available at: http://www.ontheissuesmagazine.com/2012spring/2012spring_Linden.php

Marshall, C. (2012) Lingerie football's naked sexism. Eureka Street. Available at: www.eurekastreet.com.au/article.aspx?aeid=31787

McLeod, C. (2010) Mere and partial means: The full range of the objectification of women. P. Davis \& C. Weaving (Eds.) Philosophical perspectives on gender in sport and physical activity. London: Routledge, pp.64-82.

Messner, M.A. (1988) Sports and male domination: The female athlete as contested ideological terrain. Sociology of Sport Journal, 5(3), 197-211.

Messner, M.A. (2002) Taking the field: Women and men in sports. Minneapolis, MN: University of Minnesota Press.

Messner, M.A., Duncan, M.C. \& Jensen, K. (1993) Separating the men from the girls: The gendered language of televised sports. Gender \& Society, 7(1), 121-137. doi: 10.1177/089124393007001007 
“"Legends' in 'Lingerie': Sexuality and Athleticism in the 2013 Legends Football League US Season"

by Khomutova A, Channon A

Sociology of Sport Journal

(C) 2015 Human Kinetics, Inc.

Messner, M.A., Duncan, M.C. \& Cooky, C. (2003) Silence, sports bras, and wrestling porn: Women in televised sports news and highlights shows. Journal of Sport \& Social Issues, 27(1), 38-51. doi: 10.1177/0193732502239583

Messner, M.A. \& Cooky, C. (2010) Gender in televised sports: News and highlights shows, 1989-2009. USC Dornsife. Available at: https://dornsife.usc.edu/tvsports

Moritz, A. (2011) Cheerleading: Not just for the sidelines anymore. Sport in Society, 14(5), 660-669. doi: 10.1080/17430437.2011.575109

Neuendorf, K.A. (2002) The content analysis guidebook. Thousand Oaks, CA: Sage.

Pavlidis, A. (2012) From riot grrrls to roller derby? Exploring the relations between gender, music and sport. Leisure Studies, 31(2), 165-176. doi: $10.1080 / 02614367.2011 .623304$

Petersson McIntyre, M. (2011) Keep your clothes on! Fit and sexy through striptease aerobics. In E. Kennedy \& P. Markula (Eds.) Women and exercise: The body, health and consumerism. Oxon: Routledge, pp.247-265.

Pfister, G. (2010) Women in sport: Gender relations and future perspectives. Sport in Society, 13(2), 234-248. doi: 10.1080/17430430903522954

Piachard, T. (2013) LFL Europa - A pathway for women in sport. LFL360. Available at: http://www.lfl360.com/articles/lfl-europa-pathway-women-sport-lfl360-com-thomaspiachard/

Pronger, B. (1990) The arena of masculinity: Sports, homosexuality and the meaning of sex. London: GMP.

Pronger, B. (1999) Outta my endzone: Sport and the territorial anus. Journal of Sport and Social Issues, 23(4), 373-389. doi: 10.1177/0193723599234002

Ross, B. (2007) Entertaining femininities: The embodied exhibitions of striptease and sport, 1950-1975. In J. Hargreaves \& P. Vertinsky (Eds.) Physical culture, power, and the body. Abingdon: Routledge, pp.121-141.

Roth, A. \& Basow, S. (2004) Femininity, sports, and feminism: Developing a theory of physical liberation. Journal of Sport and Social Issues, 28(3), 245-265. doi: $10.1177 / 0193723504266990$

Sabo, D. \& Curry Jansen, S. (1992) Images of men in sports media: The social reproduction of gender order. In S. Craig (Ed.) Men, masculinity, and the media. London: Sage, pp. 169-184.

Scambler, G. \& Jennings, M. (1998) On the periphery of the sex industry: Female combat, male punters, and feminist discourse. Journal of Sport and Social Issues, 22(4), 416430. doi: 10.1177/019372398022004006

Schultz, J. (2005) Reading the catsuit: Serena Williams and the production of blackness at the 2002 US Open. Journal of Sport and Social Issues, 29(3), 338-357. doi: $10.1177 / 0193723505276230$ 
“"Legends' in 'Lingerie': Sexuality and Athleticism in the 2013 Legends Football League US Season"

by Khomutova A, Channon A

Sociology of Sport Journal

(C) 2015 Human Kinetics, Inc.

Shilt, K. \& Zobl, E. (2008) Connecting the dots: Riot Grrrls, Ladyfests, and the international Grrrl zine network. In A. Harris (Ed.) Next wave cultures: Feminism, subcultures, activism. London: Routledge, pp.171-192

Shad, S. (2012) How to get men watching women's football? Have them play in lingerie. The

Guardian, 7 June $2012 . \quad$ Available at: http://www.guardian.co.uk/commentisfree/2012/jun/07/american-lingerie-footballleague-women

Shepherd, L.T. (2010) Balls out: Lingerie Football League brings guts and garters to Orlando. Orlando Weekly, 19 August 2010. Available at: http://www2.orlandoweekly.com/news/story.asp?id=14219

Shteir, R. (2013) Finding Bliss: Sport, softcore porn, or both? Stripping down the Lingerie Football League. ChicagoSide Sports. Available at: http://chicagosidesports.com/sport-softcore-porn-or-both-stripping-down-the-lingeriefootball-league/

Spicer, N. (2012) Combining qualitative and quantitative methods. In C. Seale (Ed.) Researching society and culture, $3^{\text {rd }}$ ed. London: Sage, pp.479-493.

Stokes, J. (2013). How to do media and cultural studies, $2^{\text {nd }} e d$. London: Sage.

Theberge, N. (1987) Sport and women's empowerment. Women's Studies International Forum, 10(4), 387-393. doi: 10.1016/0277-5395(87)90056-2

Thorpe, H. (2008) Foucault, technologies of the self, and the media: Discourses of femininity in snowboarding culture. Journal of Sport \& Social Issues, 32(2), 199-229. doi: $10.1177 / 0193723508315206$

Thorpe, H. (2011) Snowboarding bodies in theory and practice. Basingstoke: Palgrave Macmillan

Valentich, M. (2014) Women's toplessness on the Red Mile, Calgary, May-June 2004. Sport in Society, 17(1), 102-115. doi: 10.1080/17430437.2012.690405

Weaving, C. (2014) It is okay to play as long as you wear lingerie (or skimpy bikinis): A moral evaluation of the Lingerie Football League and its rebranding. Sport in Society, 17(6), 757-772. doi: 10.1080/17430437.2014.882905

Wensing, E.H. \& Bruce, T. (2003) Bending the rules: Media representations of gender during an international sporting event. International Review for the Sociology of Sport, 38(4), 387-396. doi: 10.1177/1012690203384001

Whitehead, K. \& Kurz, T. (2009) 'Empowerment' and the pole: A discursive investigation of the reinvention of pole dancing as a recreational activity. Feminism \& Psychology, 19(2), 224-244. doi: 10.1177/0959353509102218 
“"Legends' in 'Lingerie': Sexuality and Athleticism in the 2013 Legends Football League US Season"

by Khomutova A, Channon A

Sociology of Sport Journal

(C) 2015 Human Kinetics, Inc.

Table 1

\begin{tabular}{|l|l|l|}
\hline LFL framed as 'real' sport & Total & Average per game \\
\hline 1) Skill & 841 & 32.3 \\
2) Mentality & 306 & 11.8 \\
3) Toughness & 437 & 16.8 \\
4) Athleticism & 290 & 11.2 \\
5) Leadership & 159 & 6.1 \\
6) Statistics & 198 & 7.6 \\
7) Criticism & 512 & 19.7 \\
8) Excitement & 217 & 8.3 \\
9) Season & 290 & 11.2 \\
\hline Total & 3250 & 125.0 \\
\hline
\end{tabular}

Table 2

\begin{tabular}{|l|l|l|}
\hline Comments with 'trivialising' implications & Total & Average per game \\
\hline 10) Appearance & 5 & 0.2 \\
11) Attractiveness & 3 & 0.1 \\
12) Sexual humour & 6 & 0.2 \\
13) Lifestyles & 13 & 0.5 \\
14) 'Girls' & 58 & 2.2 \\
15) Forenames & 54 & 2.1 \\
16) 'Feminine' adjectives & 48 & 1.8 \\
17) Credit coach & 464 & 17.8 \\
18) Compare NFL & 106 & 4.1 \\
\hline Total & 751 & 28.9 \\
\hline
\end{tabular}

